\title{
Exploring Destination Identity and Destination Image in The New Age of Tourism: a Case Study of Bali Brand
}

\author{
Ni Made Asti Aksari and I Komang Gde Bendesa
}

Faculty of Business and Economic Udayana University

Correnponding author: ikgbendesa@yahoo.com

\begin{abstract}
ARTICLE INFO
Received

03 November 2015

Accepted

26 February 2016

Available online

07 March 2016
\end{abstract}

ABSTRACT

Bali's economy has grown rapidly since a decade ago. This is possible

\begin{abstract}
because tourism is growing continuously. However, tourism growth is not optimal because of insufficient promotion and tourism destination identity is unclear. The growth of Web 2.0 as a platform to share travel information has prompted tourism bodies to pay closer attention to how their destinations are perceived by target markets. Set within the context of the emergence of Web 2.0, a platform designed to enable users to generate and share information on the Internet, this paper evaluates the relationship between destination identity and destination image and adopts the view that a successful destination brand relies on the congruence between destination identity and destination image. The elements of destination identity are composed from the supply side and the elements of destination image are composed from the consumer side. The objective of exploring the alignment between these two perspectives is to propose a model to encourage the alignment of these two perspectives and evaluate the effectiveness of a destination branding strategy.
\end{abstract}

Keywords: Destination Identity, Destination Image, Destination Brand, Web 2.0

\section{Introduction}

As a tourist destination island, Bali has been well known by foreign tourists since 1920s. With tourism potentials owned by the Province of Bali, i.e. beautiful panoramas, the diversity of art and culture, then since the implementation of the Five-Year Development Phase I (1969 - 1974) the economic developments have been placed on agricultural sector and the development of tourism and handicraft industries. Giving priority to the tourism sector in the development program in the province of Bali is also based on the consideration that the area of the island is very narrow, which is only 0.29 per cent of the territory of the Republic of Indonesia. In addition, this island http://ojs.unud.ac.id/index.php/eot does not have the potential of mineral resources and energy, as well as the impossibility for the development of the large scale manufacturing industry sector.

With the growing recognition of Bali as a tourist destination, it causes Bali to be an excellent place for tourists visiting Indonesia. This is evidenced by the increasing number of tourist arrivals to Bali, as well as contribution to national tourism also increases. Visits of foreign tourists who came to Bali have increased steadily since 1969 , but they were interrupted by a decline in 2002 and 2006 caused by the Bali bombings (see Figure 1). 


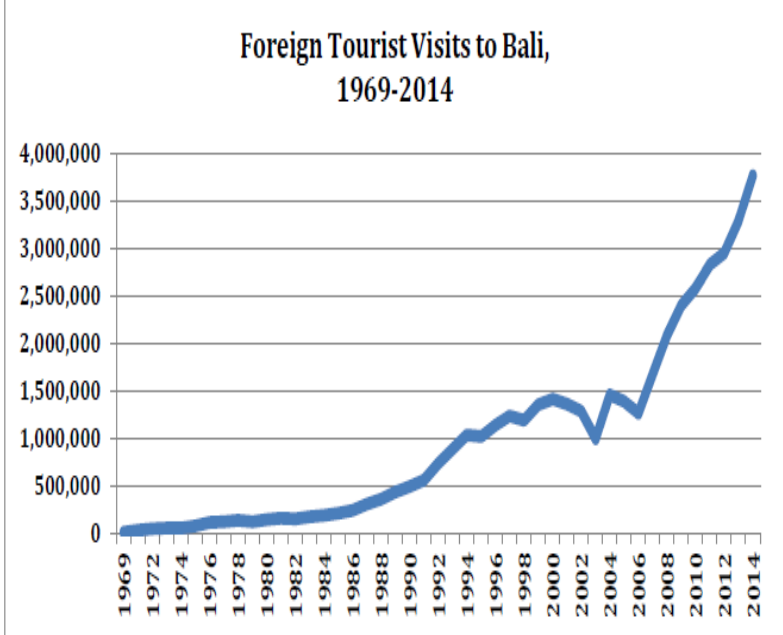

Figure 1. Foreign Tourist Visits to Bali (persons)

The development of direct foreign tourist arrivals to Indonesia and Bali during the years 2010 - 2014 can be seen in Table 1.

In 2010 tourist visits to Bali amounted to 2,385,122 people, undergoing a growth of 8.01 percent compared with the previous year. During 2011, 2012, 2013, and 2014 international tourist arrivals continued to increase, and in 2014, international tourist arrivals reached $3,766,638$ people or 14.89 percent increase from 2013. In 2010 the share of tourist arrivals to Bali was 34.06 percent, and in 2014 increased to 39.92 percent.

Tabel 1

The development of direct foreign tourist arrivals to Indonesia and Bali 2010 - 2014

\begin{tabular}{|c|c|c|c|c|}
\hline \multirow[b]{2}{*}{ Year } & \multicolumn{2}{|c|}{ Foreign Tourist Visits to Bali } & \multirow{2}{*}{$\begin{array}{c}\text { Foreign Tourist } \\
\text { Visit to Indonesia } \\
\text { (persons) }\end{array}$} & \multirow[b]{2}{*}{$\begin{array}{l}\text { Bali's Shate to } \\
\text { Indonesia }(\%)\end{array}$} \\
\hline & $\begin{array}{c}\text { Total } \\
\text { (personls) }\end{array}$ & Growth $(\%)$ & & \\
\hline 2010 & $2,385,122$ & 8.01 & $7,002,944$ & 34.06 \\
\hline 2011 & $2,576,142$ & 9.73 & $7,649,731$ & 33.68 \\
\hline 2012 & $2,826,709$ & 4.34 & $8.044,462$ & 35.14 \\
\hline 2013 & $3,278,598$ & 11.16 & $8,802,129$ & 37.25 \\
\hline 2014 & $3,766,638$ & 14.89 & $9,435,411$ & 39.92 \\
\hline
\end{tabular}

Source: Central Bureau of Statistics, 2015 (adapted)

\section{Tourism Development Policy Direction}

Tourism is an economic locomotive driving sector in Bali, with tourism the whole development of the rural community economy can thrive in Bali. Bali Provincial Government in maintaining the growth of tourism has made a variety of programs, promotional programs both within and outside the country, also carry out programs for the maintenance and improvement of quality tourism resources in Bali.

Level of performance of the programs achieved that have been implemented in the field of tourism is done by looking at several indicators as outlined below.

1) The development of foreign tourist visits during 2010 to 2014 continued to increase, in 2010 tourist arrivals to Bali as many as $2,385,122$ people, and in 2014 became 3.766.638jiwa,

2) Domestic tourist visits also increased from 2010 to 2014, in 2010 as many as 4,646,343 people, while those in 2014 totaled 6,392,460 people.

3) The contribution of the tourism sector to the GDP of the year 2010 until 2014 also underwent an increase, amounting to $61.78 \%$ in 2010 , in 2014 it increased to $66.29 \%$.

4) The average length of stay of tourist visits to Bali especially foreign tourists in 2010 was 9.49 days in 2014 was 9.1 days. Domestic tourists in 2010 had average stay for 4.20 days, whereas in 2014 it was 3.6 days.

Tourists visit by the country of origin as shown in Table 2 indicate that the major source of tourists still come from Asia, including ASEAN member countries.

Table 2

Foreign Tourist Visits by Country of Origin

\begin{tabular}{|c|c|c|c|c|c|c|}
\hline & & Country of Origin & $\begin{array}{r}2013 \\
\text { (persons) }\end{array}$ & $\begin{array}{r}2014 \\
\text { (persons) }\end{array}$ & $\begin{array}{r}2013 \\
(\%)\end{array}$ & $\begin{array}{r}2014 \\
(\%)\end{array}$ \\
\hline \multirow[t]{7}{*}{ I. } & ASEAN & & 418012 & 483487 & 12.7 & 12.8 \\
\hline & Growth $(\%)$ & & 11.89 & 15.66 & & \\
\hline & & Malaysia & 199223 & 223205 & 6.1 & 5.9 \\
\hline & & Philippines & 29840 & 32727 & 0.9 & 0.9 \\
\hline & 3 & Singapore & 138397 & 178174 & 4.2 & 4.7 \\
\hline & 4 & Thailand & 34722 & 30247 & 1.1 & 0.8 \\
\hline & 5 & Other Asean countries & 15830 & 19134 & 0.5 & 0.5 \\
\hline
\end{tabular}




\begin{tabular}{|c|c|c|c|c|c|}
\hline \multirow[t]{9}{*}{ II. } & \multirow{2}{*}{$\begin{array}{l}\text { ASIA (Non Asean) } \\
\text { Growth }(\%)\end{array}$} & 995423 & 1236816 & 30.4 & 32.8 \\
\hline & & 19.32 & 24.25 & & \\
\hline & 1 Hongkong & 37414 & 35552 & 1.1 & 0.9 \\
\hline & 2 India & 64421 & 88049 & 2.0 & 2.3 \\
\hline & 3 Japan & 208115 & 217159 & 6.3 & 5.8 \\
\hline & 4 South Korea & 134452 & 145498 & 4.1 & 3.9 \\
\hline & 5 Taivan & 127443 & 113132 & 3.9 & 3.0 \\
\hline & 6 China & 387533 & 585922 & 11.8 & 15.6 \\
\hline & 7 Other Asia & 36045 & 51504 & 1.1 & 1.4 \\
\hline \multirow[t]{5}{*}{ III. } & AMERICA & 164666 & 177940 & 5.0 & 4.7 \\
\hline & Growth $(\%)$ & 6.41 & 8.06 & & \\
\hline & 1 USA & 105863 & 111610 & 3.2 & 3.0 \\
\hline & 2 Canada & 30565 & 37532 & 0.9 & 1.0 \\
\hline & 3 Other America & 28238 & 28798 & 0.9 & 0.8 \\
\hline \multirow[t]{12}{*}{ IV. } & EUROPE & 712418 & 736188 & 21.7 & 19.5 \\
\hline & Growth $(\%)$ & 12.14 & 3.34 & & \\
\hline & 1 France & 125065 & 128288 & 3.8 & 3.4 \\
\hline & 2 Germany & 99508 & 105467 & 3.0 & 2.8 \\
\hline & 3 Italy & 28755 & 30762 & 0.9 & 0.8 \\
\hline & 4 Holland & 72275 & 76082 & 2.2 & 2.0 \\
\hline & 5 Spain & 19949 & 22789 & 0.6 & 0.6 \\
\hline & 6 Sweden & 16857 & 27345 & 0.5 & 0.7 \\
\hline & 7 Switzerland & 25406 & 24924 & 0.8 & 0.7 \\
\hline & 8 United Kingdom & 122406 & 127013 & 3.7 & 3.4 \\
\hline & 9 Russia & 79330 & 72127 & 2.4 & 1.9 \\
\hline & 10 Other Europe & 122867. & 121391 & 3.7 & 3.2 \\
\hline \multirow[t]{5}{*}{$\mathrm{V}}$. & OCEANIA & 892615 & 1050422 & 27.2 & 27.9 \\
\hline & Growth $(\%)$ & 3.8 & 17.68 & & \\
\hline & 1 Australia & 826385 & 988786 & 25.2 & 26.3 \\
\hline & 2 New Zealand & 57520 & 58142 & 1.8 & 1.5 \\
\hline & 30 Other 0 ceania & 8710 & 3494 & 0.3 & 0.1 \\
\hline \multirow[t]{5}{*}{ VI } & AFRICA & 19385 & 18137 & 0.6 & 0.5 \\
\hline & Grovth $(\%)$ & 4 & -6.44 & 0.0 & $(0.0)$ \\
\hline & 1 South Africa & 9563 & 9744 & 0.3 & 0.3 \\
\hline & 2 Egypt & 2060 & 2798 & 0.1 & 0.1 \\
\hline & 3 Other Africa & 7762 & 5595 & 0.2 & 0.1 \\
\hline \multirow[t]{3}{*}{ VII. } & CREW & 76079 & 63648 & 2.3 & 1.7 \\
\hline & Total: & 3278598 & 3766638 & 100 & 100 \\
\hline & Growth $(\%)$ & 11.16 & 14.89 & & \\
\hline
\end{tabular}

Source: Central Bureau of Statistics
Foreign tourist development based on continent is shown in Figure 2. It appears that the greatest growth comes from Asia Pacific, followed by Europe and America. Europe is a potential market for quality foreign tourists, when seen from the length of stay and expenditure during their stay in Bali.

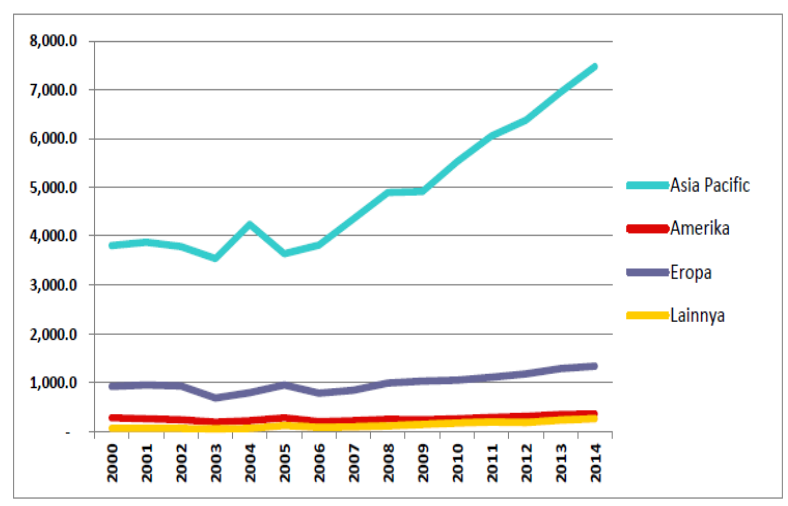

Figure 2. Development Tourists Arrivals to Bali based on Continent

In 2014, according to the development Tourists who visited Bali, the market segment was dominated by Asia (33.1\%) without Asean totaling 46.2\%, when combined with Asean, followed by Europe the number of tourists totaled $19.8 \%$ (see Figure 3). Bali should be able to bring more Tourists from Europe that has the characteristics of being interested more in local culture.

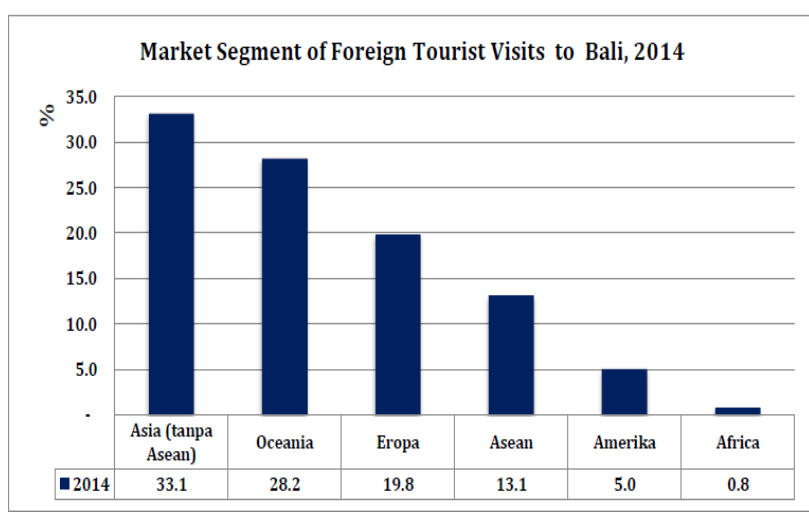

Figure 3. Market Segments of Foreign Tourists in Bali

The policy for tourism development in Bali as outlined in RPJMD 2013 - 2018 in achieving the goals and objectives from time to time during the period. Based on the analysis of the existing strengths and potentials as well as considering the availability of development funding, the policy 
is directed towards the implementation of the program priorities. Policy Directions in Implementing the Strategy "Increasing Development of Cultural Tourism and Creative Economy" in 2013-2018 are as follows:

1) Development of quality, sustainable, environmentally-based tourism and respects local genius in order to expand employment opportunities and improve the income and welfare of the community.

2) Developing a "community tourism" that can provide a double effect (multiplier effect) for the majority of local people of Bali.

3) Performing the democratization of tourism business, in order to further empower local communities, such as: giving the opportunity to the local community through a cooperative to manage the increased contribution of tourism to cultural preservation.

4) Exploring and finding new ideas or innovations to make rejuvenation or recovery of tourism life activities, so as to avoid stagnation and drastic decline in tourism activities.

5) Creating conducive environment and conditions for the development of Bali's tourism industry, supported by the synergy of various components of tourism.

6) Increasing the quantity and quality of infrastructure, maintenance of the object of both in terms of originality and cleanliness, keeping its preservation and security, empowering and providing maximum benefit to the local community surrounding the tourism object as its main buffer.

7) Providing protection and special incentives to institutions, individuals, tourism players who really devote themselves to the preservation of tourism that attract tourists.

8) Improved destination management, tourism marketing and tourism human resources.

9) Developing creative economy.

Of all strategies mentioned above, none of them consider destination identity as an important element. The government has neglected the important of identity since it presumes that Bali has already been well known in the world. It is true that beforehand, the government has created a tourism brand called Bali Shanti Shanti Shanti, but it is not effective and it is never evaluated. So, it is necessary to create a strong tourism brand

http://ojs.unud.ac.id/index.php/eot that capable to build a positive image for Bali as a memorable tourist destination.

\section{Destination Identity and Destination Image}

Interpersonal influence and word-ofmouth (WOM) are considered to be most influential on consumers' purchase decisionmaking (Litvin, Goldsmith and Pan, 2008). Today, the transmission of WOM marketing in a tourism context has changed dramatically with the introduction of the Internet, particularly Web 2.0 applications (Wenger, 2008). Web 2.0 is a platform where users and travellers can generate and share their own content on the Internet (Schegg et al., 2009). Due to the vast amount of tourism information available on the Internet, the use of Web 2.0 has become an increasingly dominant source of information for travellers when searching for tourism related information and has restructured the way people plan for and consume travel (Xiang and Gretzel, 2010).

In this context, consumers' perceived images of tourist destinations are likely to be highly affected by Web 2.0 content. Visitors' or consumers perceived images of a destination reflect the differences in information processing and interpretation among people, but destination marketers hope that consumers' perceived images of a destination is the actuality of the destination (MacKay and Fesenmaier, 2000). This implies that in projecting the desired image to the target market, there is a possibility that the marketing activities are not always effective. Indeed, the disparity between projected and perceived images may impede tourism development of a destination (Goodall and Ashworth, 2013). Goodall and Ashworth (2013) further suggested that this can lead to a gap between visitors' expectations and experiences, which may in turn lead to visitor's dissatisfaction with the destination. As such, it is important to understand the relationship between the projected and perceived images of a destination to reach an effective destination branding strategy.

The projected image of a destination can be analysed by looking at the concept of brand identity. In the context of tourism, destination identity relates to how a destination positions itself and how it wants to 
be perceived and remembered in the mind of its target markets (Wheeler, Frost and Weiler, 2011). Consequently, to achieve a destination's marketing objectives, it is essential that target markets perceive the brand in the similar way as destination identifies itself. Perceived destination image has a direct influence on consumers' intentions to visit and recommend the destination to others (Bigne, Sanchez and Sanchez, 2001). Qu, Kim and Im (2011) suggest that building a strong destination image is vital as it enables destinations to increase repeat visitation, as well as attract new tourists.

Therefore, destination marketers need to have an image formation strategy to maintain, increase, and develop their tourism industry because understanding how consumers' images are formed helps destination marketers to project the appropriate destination images to their target markets (Gartner, 1994). Commonly, target markets that have not visited the destination have limited knowledge regarding the place; quite often this limited knowledge is obtained from the information provided by the media or their social groups (Um and Crompton, 1999). This information influences tourists' image of alternative destinations. Thus, image formation is a vital component in the destination selection process of potential tourists (Gartner, 1994).

\section{A Model of Destination Branding in a Web 2.0 World}

Figure 4 presents a model of destination branding that incorporates the supplier and consumers side perspective of destination branding through destination identity and destination image where Web 2.0 is included as an influencing agent of image formation. The construct on the consumers' side is used to evaluate destination image and includes components that influence destination image formation, these being cognitive image, affective image, overall image and conative image. Cognitive image is based on the belief and knowledge, affective image refers to the feelings about a destination, while conative image is the intent or action component as it is similar to behavior (Gartner, 1994). These components are translated into the supply side, which

http://ojs.unud.ac.id/index.php/eot forms part of the self-analysis to evaluate destination identity. This research will explore Web 2.0 exchanges and not traditional one-way exchanges.

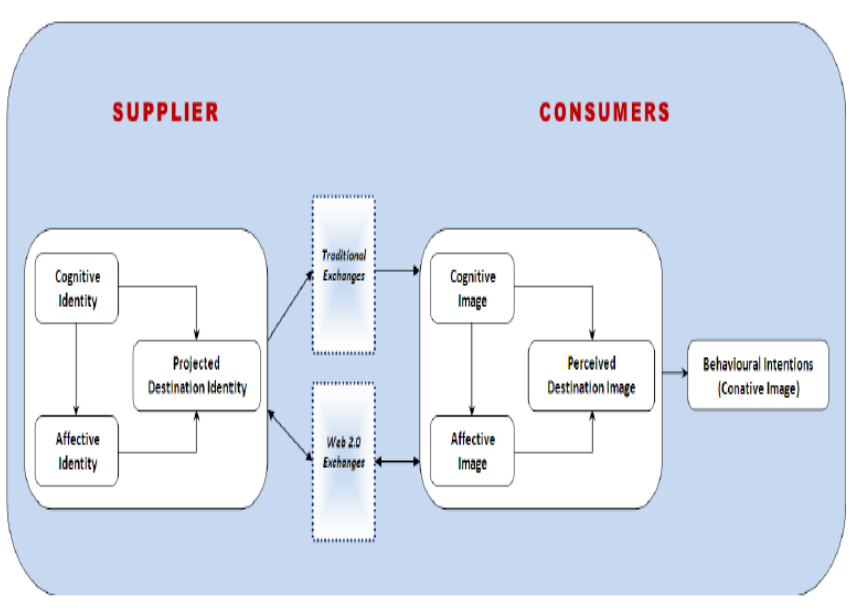

Figure 4. A Model of Destination Branding

\section{Proposed Study}

A study will be conducted to test the framework represented in Figure 4. The study will examine the efficacy of Brand Bali, which was launched in 2007. It will explore whether Brand Bali resonates with target markets and impacts their attitudes and behaviours in relation to visiting Bali. To obtain information on the projected destination identity of Bali, relevant stakeholders which are involved in the development of the tourism industry of Bali and the introduction of Brand Bali will be selected as the research sample. These will include personnel from the Indonesian Ministry of Culture and Tourism, Bali Government Tourism Office, and Bali Tourism Board. Consumers' perceptions on the perceived image of Bali will be obtained from a sample of Australian residents, as Australia is the largest market for tourism in Bali (Bali, 2011). As travel blogs operate as an informational function prior to purchase decisions (Huang, Chou and Lin, 2010), online interviews will be undertaken with respondents who are using travel blogs as a means of gathering information about Bali, to provide insights into how they perceive Bali as a tourism destination and how their image of Bali as a tourist destination influences their behavioral intentions with regard to visiting Bali. 


\section{Conclusion and Implication}

The need for tourism identity is inevitable since tourist arrivals to Bali are not yet optimum. Bali needs a strong tourism brand that is capable to create an unforgettable tourism destination. The growth of Web 2.0 as a platform to share travel information is phenomenal and accelerated, and it appears to be a marketing communications tool that will continue to evolve. With the intense competition between destinations, understanding the relationship between destination identity and destination image with Web 2.0 as an influencing factor of destination image helps improve the competitiveness of a destination.

This paper proposed a model that links destination identity and destination image. It is intended that the model will be tested with a study that will specifically add to the knowledge of branding theory in the $21_{\text {st }}$ millennium. Further research on destination branding strategy will benefit tourist destination bodies in maintaining and increasing their destination competitiveness.

\section{References}

Bigne, J. E., Sanchez, M. I. and Sanchez, J. (2001) 'Tourism image, evaluation variables and after purchase behaviour: inter-relationship', Tourism management. Elsevier, 22(6), pp. 607616.

Gartner, W. C. (1994) 'Image formation process', Journal of travel \& tourism marketing. Taylor \& Francis, 2(2-3), pp. 191-216.

Goodall, B. and Ashworth, G. (2013) Marketing in the Tourism Industry (RLE Tourism): The Promotion of Destination Regions. Routledge.

Huang, C.-Y., Chou, C.-J. and Lin, P.-C. (2010) 'Involvement theory in constructing bloggers' intention to purchase travel products', Tourism Management. Elsevier, 31(4), pp. 513-526.

http://ojs.unud.ac.id/index.php/eot
Litvin, S. W., Goldsmith, R. E. and Pan, B. (2008) 'Electronic word-of-mouth in hospitality and tourism management', Tourism management. Elsevier, 29(3), pp. 458-468.

MacKay, K. J. and Fesenmaier, D. R. (2000) 'An exploration of cross-cultural destination image assessment', Journal of travel research. Sage Publications Sage CA: Thousand Oaks, CA, 38(4), pp. 417-423.

Qu, H., Kim, L. H. and Im, H. H. (2011) 'A model of destination branding: Integrating the concepts of the branding and destination image', Tourism management. Elsevier, 32(3), pp. 465-476.

Schegg, R., Liebrich, A., Scaglione, M. and Ahmad, S. F. S. (2009) 'An exploratory field study of Web 2.0 in Tourism, Information and Communication Technologies in Tourism 2008', Retrieved September 20th.

Um, S. and Crompton, J. L. (1999) 'The roles of image and perceived constraints at different stages in the tourist's destination decision process', Consumer behavior in travel and tourism. Psychology Press, pp. 81102.

Wenger, A. (2008) 'Analysis of travel bloggers' characteristics and their communication about Austria as a tourism destination', Journal of Vacation Marketing. Sage Publications Sage UK: London, England, 14(2), pp. 169-176.

Wheeler, F., Frost, W. and Weiler, B. (2011) 'Destination brand identity, values, and community: A case study from rural Victoria, Australia', Journal of Travel \& Tourism Marketing. Taylor \& Francis, 28(1), pp. 13-26.

Xiang, Z. and Gretzel, U. (2010) 'Role of social media in online travel information search', Tourism management. Elsevier, 31(2), pp. 179. 